\title{
ENGLISH FOUNDATIONS OF US ADMINISTRATIVE LAW: FOUR CENTRAL ERRORS
}

Paul Craig*

\section{INTRODUCTION}

Philip Hamburger posed a provocative challenge to administrative law in the USA, as attested to by the title to the book, which asked whether administrative law was unlawful. ${ }^{1}$ His thesis was grounded in English administrative law, as it developed in the seventeenth century and eighteenth centuries, when lawyers in the American colonies would have been familiar with it. It is central to Hamburger's argument that much of administrative law concerning both rulemaking and adjudication was "extralegal" and was thus regarded by English law during this period.

In an earlier article I argued that this thesis was wrong as adjudged by positivist and non-positivist sources alike. ${ }^{2}$ His thesis concerning "extralegal rulemaking" had an expansive dimension insofar as it was premised on elision between prerogative and administrative rulemaking. This is mistaken, and did not represent the legal or constitutional reality in the seventeenth century or thereafter. Hamburger's thesis is also premised on a qualifying dimension, in which he sought to limit the force of his argument concerning "extralegal rulemaking" through definition of the term legislative. This facet of the argument was untenable from a conceptual perspective. This was followed by examination of the reality of

\footnotetext{
* Professor of English Law, St John's College, Oxford.

${ }^{1}$ Philip Hamburger, Is Administrative Law Unlawful? (2014).

2 P. CRaig, The Legitimacy of US Administrative Law And The Foundations of English ADMINISTRATIVE LAW, SETting THE Historical RECORD StRAIGHT, SSRN 2802784.
} 
such rulemaking in England from the sixteenth century onwards in four areas: health, safety and trade regulation; flood protection; poor relief; and excise. Such rulemaking was not regarded as extralegal.

The same flaws are readily apparent in the Hamburger's thesis on "extralegal" adjudication, which he derives from early English law. His argument contains an expansive dimension, in that it is based on an elision between prerogative and administrative adjudication. This elision is wrong, and did not represent legal or constitutional reality. Hamburger's argument also contains, as in the context of rulemaking, a qualifying dimension, in which he sought to limit the force of his principal argument concerning "extralegal adjudication", through definition of the term judicial. This aspect of the argument is conceptually untenable and did not cohere with the reality of administrative adjudication in England. This reality was revealed through examination of four areas: bankruptcy, excise, inclosure and turnpikes.

Hamburger responded to my article ${ }^{3}$ and took issue with the argument made therein. This article is a response to Hamburger's latest offering. ${ }^{4}$ The flaws in Hamburger's argument are even clearer now than hitherto, and there are numerous such mistakes. This article will, however, concentrate on four errors that are central to his thesis.

First, Hamburger's thesis rests on the argument that administrative law is extralegal, and hence illegitimate and unlawful. It is the central construct from which all else flows. In my earlier article I contended that there were serious difficulties with his conception of the term extralegal. I was wrong. It is untenable. It will be seen that this is so when judged from

\footnotetext{
${ }^{3}$ PhILIP HAMburger, ENGLISH EXPERIENCE AND AMERICAN ADMINISTRATIVE POWER.

${ }^{4}$ It should be made clear that my earlier article was concerned solely with the historical dimension to his Hamburger's thesis. I did not deal with its application, or lack thereof, to modern US law. I will not therefore respond to issues contained in Hamburger's latest article that deal with such issues.
} 
the perspective of first principle, and from the perspective of positive law. Hamburger's project is thus built on an intellectual construct that does not withstand scrutiny. It is a pillar of sand.

Secondly, Hamburger's thesis as to the legitimacy of adjudication and rulemaking by bodies charged with administration in the seventeenth and eighteenth century is wrong. $\mathrm{He}$ contends that events such as the demise of Star Chamber and the repeal of the Statute of Proclamations show that administrative adjudication and rulemaking were generally perceived to be extralegal and illegitimate in England at this time. He maintains this fixed view, and is critical of any who differ, repeatedly contending that they have ignored the historical sources. The reality is to the contrary. Hamburger's fierce insistence that his interpretation of these events is correct is combined with a signal unwillingness to consider whether that interpretation coheres with the evidence. This is a dangerous cocktail, which leads repeatedly to error. His interpretation is not correct. It is irreconcilable in empirical terms with a very great deal of regulatory legislation enacted over two hundred years, in which Parliament continually accorded the administration with powers and duties of a kind that are inconsistent with Hamburger's thesis. His argument is also incompatible with thousands of cases decided by the courts via judicial review, in which the courts accepted the grant of such authority as lawful, and did not in any way characterize it as extralegal or irregular. Hamburger's thesis is moreover defective in failing to recognize the clear normative differences between the situations where administrative adjudication and rulemaking were regarded as lawful and those where they were not.

Thirdly, the qualifications that Hamburger makes to his own thesis are conceptually incoherent and do not fit with the empirical evidence. Hamburger seeks to qualify his conclusion that administrative law is extralegal and unlawful. His modality for doing so in the context of rulemaking is through definition of legislative and non-legislative rules; while 
in the context of adjudication it is done through definition of the term judicial. These qualifications are central to Hamburger's thesis. The meaning of these terms is, however, conceptually incoherent. It is also inconsistent with much empirical evidence, since as will be seen below the legislature frequently accorded the administration power of a kind that Hamburger believes that it did not and should not have had.

The fourth error in Hamburger's thesis is methodological. Hamburger takes my earlier argument to task, contending that it was predicated on some brutish Austinian positivism, which ignored constitutional ideals. This is, as will be seen below, nonsense. It is nonetheless fitting that Hamburger should have raised the issue of methodology, since it will be seen that his own argument is premised on a constitutional methodology that is unsustainable both historically and legally. He seeks to defend a far-reaching argument that an entire body of law is unlawful, while ignoring a very considerable body of evidence in terms of legislation and judicial decisions that is inconsistent with his thesis. His argument is, moreover, premised on an indefensible distinction between 'constitutional ideals' on the one hand, and legislation and court decisions on the other, which ignores the normative values that are embodied in the latter.

\section{The MeAning OF EXTRALEgAL POWER}

\section{A. The DEFINITION}

The concept of extralegal power is central to Hamburger's thesis. It is the core of the book and the central foundation for the arguments made therein. We live by and through the use of language. It is powerful in its imagery, more especially when it is intended to have a particular effect. The term extralegal is inherently tendentious. It is laden with connotations of illegitimacy, and is intended by Hamburger to have this effect. It constitutes the foundation from which he constructs the very title of the book, which questions whether administrative 
law is unlawful. The word is used repeatedly throughout the book and the subsequent article. The meaning ascribed to the term is therefore crucial, and so too is the connection, or the lack thereof, between this meaning and the reality of administration during this period. The meaning of the term extralegal was unclear in the book, and insofar as Hamburger has clarified this he remains unaware of the profound difficulties that beset this definition on which so much of his thesis hangs.

It might be felt that the term "extralegal" would connote the absence of legal authorization, since this would be a natural meaning for it to bear and would also carry a necessary linkage with illegitimacy, since if there is no legal authorization for the power then there is no foundation for its exercise. Hamburger does not however ascribe to this meaning. He insists that the term should mean "power exercised not merely through law, but through other mechanisms - that is, not merely through legislative and judicial acts, but through other sorts of edicts, such as those of commissions". ${ }^{5}$ This echoes his earlier formulation. ${ }^{6}$

But quite apart from the question of legal authorization, there remains the underlying problem of extralegal power--the problem of power imposed not through the law, but through other sorts of commands. On this basis, when this book speaks of administrative law as a power outside the law--or as an extralegal, irregular, or extraordinary power--it is observing that administrative law purports to bind subjects not through the law, but through other sorts of directives.

Hamburger insists on this meaning, indeed he clings to it as a life raft in order to sustain his overall thesis that administrative law is unlawful, that it is a power outside the law, or to use Hamburger's own synonyms that it is extralegal, irregular and extraordinary. Hamburger claims that I ignored his meaning of the term extralegal. ${ }^{7}$ This, like much else in his article, is factually wrong. I considered his meaning and concluded that it was beset by

\footnotetext{
${ }^{5}$ Philip HAMburger, ENGlish EXPERIENCE AND AMERICAN ADMINISTRATIVE Power, at 6.

${ }^{6}$ HAMBURGer, supra note 1, at 23.

${ }^{7}$ HAMBURGER, supra note 5, at 5-6.
} 
considerable difficulties. ${ }^{8}$ Hamburger simply ignored this in his later article, which is his general strategy when faced by arguments that do not cohere with his own. It is however clear, on further reflection, that the meaning he ascribes to the term extralegal is not just beset by considerable difficulty, it is untenable. If you are going to construct a far-reaching thesis based on a particular meaning of a term then you had better make really sure that it works, more especially when that chosen meaning is the foundation for the claim that an entire body of law is unlawful. Hamburger should, therefore, have spent more time drilling down into his own chosen meaning. He might then have perceived that it is unsustainable, and that the life raft in which he set sail is fatally flawed.

\section{B. PrinciPle ANd Positive LaW}

The great majority of administration during the seventeenth and eighteenth centuries took the form of individualized determinations made by the body charged with administering that particular regime, whether that was the excise, sewers, inclosures, the poor law, trade regulation or police power. It was in modern parlance administrative adjudication. The very great majority of this administration, circa 95\%, was carried out pursuant to express statutory authority, whereby Parliament invested bodies such as commissioners or justices of the peace with the power and duty to apply the law in their designated area. The exercise of such power had nothing whatsoever to do with the prerogative, howsoever that term is defined, an issue to which we shall return in due course.

It is instructive to consider Hamburger's meaning of the term "extralegal" against the preceding backdrop. There was clearly statutory authorization for the exercise of such power, so in what sense was this "power imposed not through the law, but through other sorts of

\footnotetext{
${ }^{8}$ CRAIG, supra note 2, at 31-4.
} 
commands"; in what sense should such power, or the exercise thereof, be regarded as falling "outside the law or as an extralegal, irregular, or extraordinary power"; in what sense can it be correct to say that "administrative law purports to bind subjects not through the law, but through other sorts of directives"? The reality is that such characterization makes no sense when applied to the many areas adumbrated above where administration was prevalent, and that is so when viewed from the perspective of principle and from that of positive law.

\section{Principle}

Consider the issue first from the perspective of principle. Hamburger's conception of the extralegal is predicated on the assumption that power can only be regarded as being exercised through law if it is an act of the legislature or the courts. If an act is not a legislative act, or an act of the courts, then it must be characterized as a power imposed not through law, but through some extralegal, irregular and extraordinary command outside the law. This premise is apparent from the preceding quotations and many others throughout his work. Thus Hamburger states that extralegal lawmaking and extralegal adjudication "both are unlawful for the same reason: that they bind through edicts other than acts of the legislature or of the courts"; 9 and in a similar vein he speaks of the "danger that government can create legal obligation through edicts that are not those of the legislature and the courts."10 This conception of the extralegal is not accepted in any common law or civil law regime. It is wrong for the following reasons.

First, it is analytically erroneous since it conflates two distinct issues: the nature of an act; and whether the power that flows from the act can be said to be exercised through law with the capacity to bind and create legal obligations. Thus for Hamburger acts of the

\footnotetext{
${ }^{9}$ HAMBURGER, supra note 5, at 27.

${ }^{10}$ Id. at 9-10.
} 
legislature and the courts are the only instances where power can be regarded as being exercised through law, and the only instances where binding legal obligations can be created; therefore administrative adjudication and rulemaking are ipso facto extralegal. This is quite wrong. It is axiomatic in all legal systems that a wide range of acts are exercised 'through law', which bind and create legal obligations. The making of a contract is self-evidently not an act of the legislature or the courts as those terms are used by Hamburger, but contracting power is exercised through law, and contracts create legally binding obligations for the parties. The principles concerning contract law are laid down by the legislature and the courts, as they are in all areas of the law. An agreement duly made within these precepts has legal force unless the contracting party can show a vitiating factor. The courts do not demand that they make the initial or final determination of a legal dispute, as attested to by widespread use of arbitration, mediation and the like. The same analysis is applicable to any area of law. The acquisition of property is not an act done by the legislature or the courts. The owner is nonetheless invested with power that takes the form of legal rights and obligations, the content of which is laid down by the legislature and the courts. The property owner can use such power to, for example, exclude a trespasser or charge for the use of his land. The exercise of such power within the boundaries of the relevant rules is lawful. There is no requirement for authorization from a court before exercising such power, nor do the courts demand that they determine a legal dispute, which can be resolved if the parties so wish through other legal means. The same reasoning is applicable to administrative law. Administrative adjudication and rulemaking are not acts of the legislature or the courts, but administrative power is exercised through law and creates legal obligations for those who come within its remit. The legal authority to undertake such measures is derived from statute that authorizes and mandates the exercise of such power, and is regulated by the courts through principles of judicial review. Administrative adjudication or rulemaking bind the 
relevant addressees, commonly a single person in the case of adjudication, and a wider group in the context of rulemaking. The courts do not demand that they should be the initial decision-makers on such issues, and they treat the administrative determination as legally valid and binding, subject to judicial review. ${ }^{11}$

Secondly, Hamburger's thesis is conceptually wrong. The administrative decisions do not, as he maintains, bind because of some edict or directive as opposed to the law. To the contrary, the decision, directive or edict has binding legal quality precisely because it is made pursuant to legislation, a valid source of legal authority, which mandated the making of such measures to fulfil the legislative schema. The decisions or edicts made by the administration pursuant to legislative duty or power are not therefore some extralegal form of command. They are, to the contrary, the clearest expression of a duty that is both founded on and exercised through law that one could imagine. There is no sense in which this power, or its exercise, is extralegal, irregular, or extraordinary; and there is no sense in which the decisions thus made should or could be regarded as directives that bind subjects other than through law. To the contrary, the fulfilment of a legal duty cast on the administration by statute has always been legal, regular and ordinary, and has been so regarded by the courts. The particular nomenclature attached to such decisions is irrelevant in this respect. From the perspective of principle it matters not a jot whether the relevant determinations are called administrative decisions, edicts, directives or some other name. The administrative determinations are invested with legal authority because the administration is fulfilling a legal duty imposed by

\footnotetext{
${ }^{11}$ It is readily apparent from the preceding analysis that the scope of the binding obligations will vary depending on the nature of issue: in contract they will prima facie exist ad personam between the contracting parties; in property the binding obligations may also be in rem against the whole world; while the fiduciary, such as the company director, will owe duties to a range of people. Administrative adjudication will commonly only bind the immediate person or persons who are the addressees of the decision; rulemaking will perforce bind the wider range of people that come within the remit of the rule.
} 
the enabling legislation. Hamburger's characterization of administrative law binding individuals not through law, but through other forms of directive, is therefore conceptually wrong. ${ }^{12}$

Thirdly, there is no normative basis for the assumption that power can only be regarded as being exercised through law in relation to acts of the legislature and the courts. Parliamentary sovereignty in its modern sense post-dates the seventeenth century revolution, but even before that statutes duly enacted had the legitimacy that flowed from securing the imprimatur of the three constituent parts of the legislature in the prescribed manner. The statutes charged the administration with particular tasks, investing them with duties and powers to effectuate the desired ends. Statutes require administration, and this was done through exercise of a legal authority duly vested in the body chosen by Parliament to perform the task. The administration would routinely make the very decisions that it was charged with making. The power to make such decisions was clearly a power imposed through law, and the decisions thus made were clearly invested with legal authority. There is good normative reason for the default position to be that respect is accorded to the parliamentary choice as to mode of administration. There is good normative reason to ensure that the administrative decisions are subject to judicial oversight to ensure that they comply with the requisites of procedural and substantive review, as has been the norm for circa four hundred years. There is no normative reason for characterizing the faithful fulfilment of those administrative duties through the making of the administrative decisions stipulated by the empowering legislation as being the exercise of extralegal, irregular or extraordinary power. There is no normative

\footnotetext{
${ }^{12}$ There may be instances where the administration purports to act through some form of soft law, and legal systems deal with this issue in different ways. Hamburger is however advancing a general thesis concerning the extralegal nature of administrative law, which is clearly intended to cover the paradigm instance of binding administrative adjudication.
} 
reason for demanding that the courts must be the initial decision-makers in such instances, and this has never been part of English law.

Fourthly, Hamburger's argument is dependent on disaggregation of the legislation and its terms that makes no principled sense. He regards legislation as a quintessential instance of power exercised through law; he also regards the administrative decisions made pursuant thereto as extralegal, irregular and extraordinary. This begs the very question of what he means when he talks of legislation in this respect. A statute is a measure enacted in a prescribed manner. It has content, without which it is an empty vessel. The content consists of the ends stipulated therein, and the means through which those ends are to be attained. Hamburger's thesis is premised on a false dichotomy. The 'legislation' is power exercised through law and legitimate; the 'content' thereof, insofar as it relates to the decisions to be made for its administration, is said to be extralegal, irregular and extraordinary, notwithstanding the fact that such decisions are specified in the legislation as the mode of fulfilment of the legislative schema. There is no principled foundation for this dichotomy.

Fifthly, from a consequentialist perspective Hamburger's thesis means that legislation could in many instances never be 'lawfully' administered. We live in a world of mass administrative justice. Legislation when enacted requires administration. For Hamburger only acts of the legislature and the courts are cloaked with legality, all else is extralegal. The application of the legislation by the administration is by definition not a legislative act in Hamburger's terms, and the existence of judicial review does not suffice to render it legitimate. The initial determination must then be made by a court, which was impossible in the seventeenth century, and would be ever more so now. This would, moreover, have distributive consequences, since the costs of satisfying his precepts would entail a radical shift in resources towards adjudication by courts, with a consequential shift of resources away from the substantive issue that the legislation was intended to address. 


\section{Positive law}

Consider now the issue from the perspective of positive law. A test as to whether Hamburger's thesis is sustainable must be whether it comports with how the decisions made by the administration were viewed by the courts. If his thesis is correct then this would assuredly be supported in the courts' jurisprudence, which would furnish evidence that administrative decision-making was perceived to be extralegal and irregular in the manner for which Hamburger contends. The reality is quite the contrary. The courts articulated a consistent view concerning the status of administrative decisions. It was based on first principle, and it was wholly inconsistent with Hamburger's thesis. The judicial view was as follows.

Where Parliament gave the administration a task it thereby authorized and obliged it to fulfil its remit. The administrative decisions were regarded by the courts as legally binding, subject to judicial review, and individuals were bound by such decisions because the administration had exercised a legal power or duty derived from the enabling legislation. The need for legal authority to act was central to English judicial review, and in the very great majority of cases it derived from the empowering statute. If the administration had been exercising a 'power outside the law' its determination would have been per se null and void. The legally binding nature of the primary administrative decision was reinforced by the development of secondary legal norms to decide when the administration could depart from, revoke or change its initial determination.

These principles carried over to the remedial level through the prerogative writs, which were the remedies used by the courts in a direct action for judicial review. The remedies included the power to quash and prohibit, thereby ensuring that the administration remained within its remit. The courts also had the power to command, exercised through the 
writ of mandamus, to ensure that the administration fulfilled the legal duty cast on it. The remedies for direct challenge were complemented by those for collateral attack, commonly in the form of a tort action. The constituent elements of the relevant cause of action varied, but a common element was that the claimant needed to show that the administration lacked legal authority to do the thing in question, as exemplified by the tort of breach of statutory duty. The remedial provisions in English administrative law were thus predicated on the fact that the administration was subject to a legal duty to act derived from the empowering legislation, which could be enforced either through mandamus, or through a damages action.

The administrative decisions were not therefore regarded as some form of directive that purported to bind the subject otherwise than through the law. They were not perceived as "irregular commands"; ${ }^{13}$ nor were they seen as "extraordinary substitutes" for ordinary adjudication; ${ }^{14}$ and nor were they viewed as an exercise of "mere state power" outside the law. ${ }^{15}$ To the contrary, the administration was fulfilling through the law the very mandate accorded to it by Parliament, and this legal duty could be enforced either through mandamus, or through damages via a tort action. It was for Parliament to decide on the institutional structure through which such decisions were made. Parliament did not proceed on the assumption that administrative adjudication pursuant to the empowering statute was unlawful or extralegal, and nor did the courts.

It is important to understand that the superior courts did not seek to arrogate initial jurisdiction in such cases to themselves. Nor did they believe that decisions made by administrative authorities pursuant to statute would necessarily have to be sanctioned by some lower court before they became effective. The primary legislation might provide for

\footnotetext{
${ }^{13}$ Id. at 24 .

${ }^{14} I d$. at 24 .

${ }^{15}$ Id. at 24.
} 
this, in which case it would be duly enforced by the superior courts on review. Where there was no such provision, the superior courts did not require it.

The same was true in relation to matters of appeal. The legislation might provide for some measure of appeal to a lower court, in addition to exercise of the superior courts' inherent jurisdiction via judicial review. Such appeal was however de facto and de jure predicated on the assumption that the initial administrative determination was legally binding, subject to exercise of any appeal. Such appeals were commonly time limited and there were disincentives to challenge the initial legal determination, since if the appellant lost he would be liable for costs, and in some instances the penalties were increased.

What the superior courts did demand is that the decisions of such bodies should be amenable to judicial review. This was the focus of seventeenth century thought. The judicial approach in relation to the administrative state broadly conceived was to ensure that the decisions were amenable to review in accord with the procedural and substantive precepts that were developed during this time. To this end the courts developed procedural principles of natural justice that required the administration to be unbiased and to hear the affected individual before the decision was made. The courts also applied substantive principles concerning error of law and error of fact, as well as constraints on the exercise of discretion cast in terms of rationality and proportionality.

There is, moreover, a further major difficulty with Hamburger's thesis in terms of positive law. If you make far-reaching claims concerning the legitimacy of an entire body of law based on a particular proposition then you must not only shake the intellectual tree very hard to ensure that the proposition makes sense in that legal context, which it does not, but you must also consider its implications for other areas of the law and whether they withstand scrutiny. Hamburger does not take this latter step, and if he had done so it would have furnished further evidence as to why his conception of the extralegal is indefensible. 
The reason is not hard to divine. Statutes regularly impose a host of powers and duties on private parties, including corporations. There is, and always has been, a wide array of such legislation. From an historical perspective such duties could be found in statutes concerning diverse areas such as excise, sewers, trade regulation, and land use. In the modern day they are commonly imposed in areas ranging from health and safety at work to the running of clinical trials, and from the regulation of securities markets to the rules applicable for competitive sport. Such legislation frequently imposes duties on a private individual, which can bind other individuals. A rail company may have an obligation to ensure that stations are operated in a safe manner, and this may be given effect through a decision to close the entrance to a station for period of time if the platforms become too overcrowded; the decision will perforce limit the freedom of passengers to move freely to their chosen destination. A factory may be under an obligation to ensure a safe system of work, and may make decisions that limit the clothing that people can wear to work, where they can walk within the factory premises, and whether they can listen to music while performing their assigned task; the decisions will perforce limit the antecedent freedom of action of those affected.

These decisions and thousands more like them are regarded as legally binding under English law, and always have been. The decision made by the private party is recognized as having legal authority derived from the fact that the statute imposes a legal duty, which can be enforced through an action for breach of statutory duty if that party fails to comply with the requisite obligation. By parity of reasoning the person affected by the decision is legally obliged to comply on pain of whatever penalties may be prescribed by the statute. The private party may be empowered to levy that fine, or to impose other penalties such as termination of employment for failure to comply with the relevant decisions. There is no sense in which such decisions made pursuant to the statute were regarded as extralegal, 
irregular or extraordinary. There is no sense in which the decisions were conceptualized as being made by virtue of a power outside the law.

Hamburger might attempt to distinguish the two situations and provide some meaningful rationale as to why they should be conceptualized differently, such that he can retain his characterization of administrative law as extralegal, without thereby painting the situation involving the private party with the same brush. There is, however, no conceptual distinction between this situation and the paradigm within administrative law. In both instances there is a statute that vests powers and duties in private parties or administrative authorities. In both instances the decisions made pursuant to the statute are recognized as legally binding, subject to any successful challenge before a court. In neither instance is the making of the decision seen as being extralegal, irregular, extraordinary, or as an exercise of power outside the law. It is, to the contrary, seen as the proper fulfilment of a legal obligation imposed on the private party or administrative authority pursuant to the statute. This point is thrown into sharp relief by the realization that it can be fortuitous whether regulatory legislation imposes obligations directly on private parties, or whether it does so through the interposition of an administrative authority. It would therefore be absurd to suggest that the decision-making power can be regarded as lawful when exercised by the private party, but that it must then be seen as extralegal when the very same duty is imposed on an administrative authority.

Hamburger might alternatively rub his hands with intellectual relish and begin the planning of a series of books that would keep him busy for the remainder of his career. I feel sure that he could interest a publisher in a series of titles. He might begin with 'Is Health and Safety Law Unlawful' and move on from there, although if he prefers to start with 'Is Statutory Tort Law Unlawful' that would be fine too. 


\section{Conclusion}

The reality is that the foundation for Hamburger's claim concerning the unlawful nature of administrative law is built on sand, insofar as it is dependent on a meaning of the term extralegal that does not cohere with principle or positive law. Hamburger's conception of the extralegal does not cohere with principle; the thesis is inconsistent with positive law in terms of the way in which the courts conceptualized the nature of administrative decisions within the legal order; and the thesis runs directly counter to the way in which the legal order conceptualizes decisions made pursuant to statute by private parties.

There may well be constitutional limits as to what the administration should be allowed to do. Nothing in the preceding analysis denies this. The nature of such limits must, however, be thought through in relation to the particular legal order, and care must be taken to ensure that the limits reflect and cohere with the principles that underpinned that legal order, taking fully into account legislative and judicial practice in this regard.

Hamburger's concept of the extralegal provides no assistance in this respect. It does not cohere with principle or positive law, and it will be seen below that the qualifications that Hamburger makes to his conception of the extralegal are fraught with conceptual problems and unsupported by empirical evidence in terms of English legislative and judicial practice. ${ }^{16}$

\section{Prerogative AND StATUtory AdMINISTRATIVE Power}

\section{A. LEGAL AND CONSTITUTIONAL LIMITS}

The second flaw in Hamburger's construct is that his depiction of what was regarded as lawful and constitutionally legitimate in English law is wrong. The picture that he paints of the legal and constitutional limits of administrative law does not accord with reality. In reaching his conclusion Hamburger repeatedly elides prerogative and administrative power.

\footnotetext{
${ }^{16}$ See below Part III.
} 
Thus we are told that administrative legislation or rulemaking constitutes a return to prerogative lawmaking, and that statute cannot cloak it with constitutional legitimacy; ${ }^{17}$ in similar vein we are told that "executive lawmaking creates an extralegal regime - a regime of legislation outside the law and, indeed outside the constitutionally established lawmaking institutions and processes". ${ }^{18}$ The Statute of Proclamations ${ }^{19}$ whereby Henry VIII secured statutory authority for his royal proclamations is regarded as "an early version of the sort of statutes that nowadays authorize administrative rulemaking"; ${ }^{20}$ the statute was repealed in 1547 but lived on as a "memorable warning against legal authorization for prerogative or administrative power." 21 The same theme appears repeatedly in his discussion of adjudication. He points to the tensions between what he terms "prerogative or administrative adjudication" $^{, 22}$ and the jurisdiction of the ordinary courts. ${ }^{23}$

The rationale for the elision is readily apparent, given the underlying thesis that informs Hamburger's project. He wishes to sustain the argument that administrative law is unlawful, in the sense that it is an extralegal regime, using that term in the manner discussed in the previous section. The ready equation of prerogative and administrative rulemaking, and the similar running together of prerogative and administrative adjudication, fit nicely into this agenda. This is more especially so because the term prerogative carries the connotation of something irregular, which gels neatly with the overall aim of showing that administrative law entails the use of extralegal power; even better when all administrative adjudication can

\footnotetext{
${ }^{17}$ HAMBURGER, supra note 1 , at 48-9, 56-7, 63, 82, 128.

${ }^{18}$ Id. at 83 .

${ }^{19}$ Statute of Proclamations 1539, 31 Henry 8, c. 8.

${ }^{20}$ HAMBURGER, supra note 1 , at 36.

${ }^{21}$ Id. at 38 .

${ }^{22}$ Id. at 136.

${ }^{23} I d$. at $136-7$.
} 
be likened to Star Chamber, given the negative connotations that attend mention of this name. This is exemplified by the repeated statements to the effect that "my thesis is that administrative power revives the extralegal character of the absolute prerogative,"24 and that "the absolute prerogative power and traditional English administrative power both involved forms of extralegal power". 25

Hamburger's argument is wrong for the reasons that I set out in detail in the earlier article, and summarize briefly here. English law provides two lawful grounds for state action, the prerogative and statute. The prerogative is a species of executive power that allows the executive to act in certain instances even though there is no statute, such as the prerogative power to conclude a treaty. The application of these precepts to rulemaking and adjudication by the administration was as follows.

There were two constraints on rulemaking in England. First, the courts determined the existence and extent of prerogative power. The Case of Proclamations ${ }^{26}$ is clear constitutional authority for the proposition that the prerogative that enabled the Crown to regulate some aspects of trade did not extend so as to accord it a generalized regulatory power to make rules concerning trade broadly conceived. The message was clear: if the King wished to attain regulatory goals this had to be done by and through Parliament. The second constraint concerned statute. The grant of a general statutory authority akin to the Statute of Proclamations $1539,{ }^{27}$ would have been regarded as constitutionally illegitimate in the

\footnotetext{
${ }^{24}$ HAMBURGER, supra note 5, at 28.

${ }^{25}$ Id. at 28 .

${ }^{26}$ (1611) 12 Co. Rep. 74.

${ }^{27}$ Statute of Proclamations 1539, 31 Hen. 8, c. 8, "The King for the Time being, with the Advice of his Council, or the more Part of them, may set forth Proclamations under such Penalties and Pains as to him and them shall seem necessary, which shall be observed as though they were made by Act of Parliament; but this shall not be prejudicial to any Person's Inheritance, Offices, Liberties, Goods, Chattels or Life; and whosoever shall
} 
seventeenth century, since the legislation gave an open-ended substantive regulatory power to the executive, which was not subject-matter specific, to make rules without further recourse to Parliament, which rules would then be given the force of an Act of Parliament. ${ }^{28}$ Parliament's sovereignty would have been an empty vessel, since the King would have been given authority to legislate in his own name, without the need for approval from the House of Commons or House of Lords. It is for this reason that the statute was regarded as constitutionally illegitimate, and was seen in Lockean terms as an unjustified delegation of legislative authority.

Rulemaking by the administration was, nonetheless, different. The paradigm instance was rulemaking by the administrative authority pursuant to a particular statute that accorded it express power to make rules for the particular area. It was not extralegal, it was not extraordinary and it was not irregular. The administrative authority was charged by Parliament with a specific task, such as poor relief, the collection of tithes or river defence, and the legislature decided to grant it rulemaking power. The conditions for the making of such rules could perforce vary, as could the authorization that would have to be secured before such rules could take effect. It was axiomatic that the rules thus made would be bounded by the terms of the primary legislation, and that such rules were hierarchically inferior to the primary legislation pursuant to which they were made. It was also axiomatic that the rules thus made could be subject to oversight and judicial review in the ordinary courts. Grant of rulemaking authority was not taken lightly. The Lockean injunction against exercise of legislative-type power by a body other than the legislature may well have been the willingly offend any article contained in the said Proclamations, shall pay such Forfeitures, or be so long imprisoned, as shall be expressed in the said Proclamations; and if any offending will depart the Realm, to the Intent he will not answer his said offence he shall be adjudged a Traitor."

${ }^{28}$ Historical opinion continues to be divided as to its object and effect, M.L. Bush, The Act of Proclamations: A Reinterpretation, 27 AMERICAN JOURNAL OF LEGAL HISTORY 33 (1983). 
principled starting point, but it was qualified by legislative practice. Legislative authorization of administrative rulemaking in a particular statute was not regarded in the same way as claims to generalized prerogative regulatory power of the kind made in the Case of Proclamations, or as an open-ended grant of executive regulatory authority such as the Statute of Proclamations, which invested the regulations thus made with the force of primary legislation.

Consider now adjudication. There were in two respects in which adjudicative power independent of the ordinary courts was constrained, and neither impacted on the paradigm instance of such power exercised by the administration. First, the courts placed limits on the exercise of prerogative adjudication. Prohibitions del Roy ${ }^{29}$ is authority for the proposition that the King had no judicial power to resolve legal issues independent of statute and independent of the established courts. The prerogative did not accord the King this judicial power, which resided with the established courts. Second, by the mid-seventeenth century the courts would equally frown on a statute that accorded the monarch, or some other executive authority, a general adjudicatory power, free from constraint by the ordinary courts, more especially if, as with the Star Chamber, it was under the control of the executive, in the sense of serving its will.

Adjudication by the administration was different. The paradigm during this period, which represented circa $95 \%$ of administration, was the grant of responsibilities to the administrative authorities pursuant to regulatory legislation embodying valuable public objectives, which perforce had to be enforced through decisions made by those accorded responsibility in the legislation. The administration was given statutory legal duties to fulfil, it had a legal duty to take the decisions demanded of it by the legislation, which were binding subject to judicial review in the ordinary courts. This adjudication was not regarded as

\footnotetext{
${ }^{29}$ (1607) 12 Co. Rep. 63.
} 
extralegal, it was not irregular, and it was not extraordinary. The monarch's prerogative claim to general judicial authority independent from the ordinary courts was wholly different from an administrative authority fulfilling its statutory mandate by making decisions demanded of it by the empowering legislation, which were then subject to review by the regular courts.

\section{B. GENERALIZATION: EMPIRICAL AND NORMATIVE FOUNDATIONS}

Hamburger first response to the preceding argument is predicated on a view concerning Star Chamber and the Statute of Proclamations. He seeks to generalize from the reasons for their demise and argues that they reveal the general constitutional infirmity of administrative adjudication and rulemaking. He claims that they were regarded by English law as extralegal, and were seen as unchecked, absolute prerogative power. Hamburger contends that his meaning of the term extralegal is warranted in relation to the demise of the Star Chamber. He argues that it fell because it operated abusively and extralegally. He contends moreover that Parliament and the courts in the seventeenth century regarded the grant of specific statutory authority to the administration in the same way, such that it too was seen as exemplifying the same flaws and was perceived as unconstitutional in equal measure. ${ }^{30}$

Hamburger is fixated by his own thesis, which distorts judgment and reason in equal measure. He dearly wants all exercise of adjudicative power to be regarded in the same light as the Star Chamber. He regards this as exemplifying the "extralegal character of the absolute prerogative [which] has been revived by contemporary administrative power". ${ }^{31} \mathrm{He}$ argues that the parliamentary rationale for the fall of Star Chamber in 1641 meant that any administrative adjudication was tainted by the same brush, and that any attempt to distinguish them is doomed to failure. He bemoans the fact that argument to the contrary fails to respect

\footnotetext{
${ }^{30}$ HAMBURGER, supra note 5, at 9-10.

${ }^{31}$ Id. at 3.
} 
the historical sources, which he claims support his generalization from Star Chamber to administrative adjudicative authority in general. Hamburger, by parity of reasoning, dearly wants all administrative rulemaking power to be viewed as equivalent to the Statute of Proclamations 1539, such that any rulemaking is treated conceptually as the exercise of some absolute and unchecked prerogative power, which is extralegal. ${ }^{32}$

This argument does not withstand examination in empirical or normative terms. Hamburger's argumentation combines fierce insistence that his interpretation of the significance of events such as the fall of the Star Chamber is correct, combined with a signal unwillingness to consider whether that interpretation coheres with the evidence. This is a dangerous cocktail, which repeatedly leads to error.

The claim is wrong empirically, and does not cohere with Parliamentary and judicial practice. Parliament enacted thousands of regulatory statutes, ${ }^{33}$ which expressly accorded specific adjudicative responsibilities to the administration, and regularly included powers that Hamburger regards as beyond the pale. It did so before the demise of Star Chamber, contemporaneous with it and continuously thereafter. The grant of such power and duty to the administration was not perceived as analogous to Star Chamber. To put the same point conversely, the sovereign Parliament repeatedly enacted such measures and repeatedly reinforced such grants of power where experience revealed gaps in the pre-existing legislative schema, and there was no indication that it considered the administration of such schemes to be extralegal in the manner for which Hamburger contends. This is equally so in relation to the courts. They articulated constitutional principles concerning the relationship between

\footnotetext{
${ }^{32} I d$. at $9-10$.

${ }^{33}$ Thus in the period between 1690-1790 15,000 Bills were laid before Parliament, 80\% of which issued as

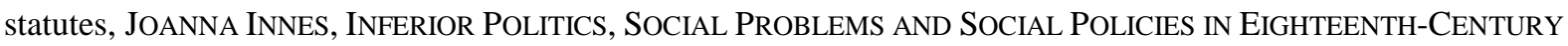
BRITAIN (2009), pp. 26-27.
} 
different branches of government, as exemplified by the twin decisions in the Case of Proclamations $^{34}$ and Prohibitions del Roy; ${ }^{35}$ they also developed and applied the principles of judicial review that governed relations between the individual and the administration. They were activist and forthcoming in both respects. There is, however, no indication in the thousands of cases on judicial review that the courts regarded such administrative decisionmaking as analogous to Star Chamber. To the contrary, administrative decisions were seen as the natural and legitimate fulfilment of Parliamentary will as expressed in the empowering legislation. The empirical evidence therefore furnishes no foundation for Hamburger's claim.

This is unsurprising, since there were clear normative differences between the two situations, which were as readily apparent to Parliament and courts in the seventeenth century as they are now. It requires no superior intellect to compare and contrast the following. The Star Chamber embodied a general adjudicatory power. It had scant jurisdictional limits, was free from constraint by the ordinary courts, was under the control of the executive, imposed arbitrary far-reaching punishment and came to serve the monarch's will. It was moreover perfectly possible for Star Chamber cases to be adjudicated before the ordinary courts. The paradigm instances of administration, such as the commissioners for bankruptcy, inclosure or excise, were grounded on specific legislation that expressly mandated them to administer a particular legislative schema. Their decisions were always subject to judicial review; they were subject to appeal where the statute so provided; there was some political accountability; and in certain instances there were also internal administrative checks. The ordinary courts were moreover in no position to exercise primary jurisdiction over such cases, and the administrative decisions were invested with legal authority subject to judicial review or appeal.

\footnotetext{
${ }^{34}$ (1611) 12 Co. Rep. 74.

${ }^{35}$ (1607) 12 Co. Rep. 63.
} 
It equally requires no superior intellect to distinguish in normative terms between the types of rulemaking that were regarded as constitutionally illegitimate and those that were not. The Case of Proclamations established that the monarch did not possess a generalized regulatory power to make trade rules pursuant to the prerogative, which would have bypassed Parliament. The Statute of Proclamations 1539 was regarded as constitutionally infirm since it vested in the executive an open-ended power to make rules without further recourse to Parliament, which would then be given the force of an Act of Parliament, with the consequence that Parliament's sovereignty would have been an empty vessel. Parliament was wary of delegation of rulemaking authority, but legislative authorization of administrative rulemaking in a particular statute was not regarded in the same way as claims to generalized prerogative regulatory power of the kind made in the Case of Proclamations that would have bypassed Parliament, or as an open-ended grant of executive regulatory authority such as the Statute of Proclamations, which invested the regulations thus made with the force of primary legislation. By way of contrast the rules made pursuant to a specific statute dealing with, for example, prevention of health hazards were subject to legal oversight through judicial review; they were bounded by the terms of the primary legislation; they involved no circumscription of Parliament's primary legislative authority; and nor were the rules invested with the same status as primary legislation. There were, moreover, good reasons to invest the administration with such rulemaking capacity, which mirrored those deployed in the modern day: rules can foster the treatment of like cases alike; they can guide and shape conduct in advance; and they can be a more efficient way of fulfilling the legislative mandate as compared with pure ad hoc decision-making. Hamburger may not believe that these features serve to distinguish such rules from those that were regarded as constitutionally illegitimate. He states repeatedly that they too should be regarded as prerogative power that is absolute, unchecked and 
extralegal, but provides no reasoned basis for such conclusion, because there is none. Asseveration is not argumentation. The situations are clearly different in normative terms.

\section{Conceptual Classification: EMPIRICAL ANd Normative Foundations}

Hamburger has a second response to my argument concerning the legal and constitutional limits to adjudication and rulemaking in English law. He seeks to rebut the argument that he elides prerogative and administrative power by contending that I have made "an astonishing claim about prerogative power" 36 to the effect that "prerogative was unauthorized by and unlimited by statute". ${ }^{37}$ Hamburger is in full flow at this point and his indignation veritably leaps from the page when he describes my claim as "nonsense". ${ }^{38}$ Hamburger's fulminations notwithstanding, his argument does not withstand examination from either an empirical or from a normative perspective.

Consider the empirical perspective first. Hamburger might have forestalled the rise in blood pressure that undoubtedly attended his indignation had he taken more care when reading my argument. What I said was that the prerogative entails a ground of lawful authority in English law that exists independently of statute, in the sense that the executive can lawfully act within the bounds of an admitted prerogative even though there is no legislative authority for the action. The courts from the seventeenth century onwards demarcated the existence and extent of such prerogative power. This is first year English constitutional law. I did not say that the prerogative was unlimited by statute, nor did I intimate this in any way whatsoever. This is because it is equally part of first year English constitutional law that Parliament can limit the prerogative by statute, a topic on which I have

\footnotetext{
${ }^{36}$ HAMBURGER, supra note 5 , at 3 .

${ }^{37} I d$. at 3.

${ }^{38} I d$. at 3.
} 
written at some length. ${ }^{39}$ It can do so expressly, and it can do so impliedly, such that when statute and the prerogative touch on the same subject matter the executive must follow the statutory dictates and cannot choose to proceed by the prerogative where it believes that it would be more advantageous to do so.

Consider now the normative dimension concerning the elision of the prerogative and statute. Hamburger believes fervently that the two species of power overlap. He trumpets loudly the egregious intellectual error that I have committed by not recognizing that some prerogative powers had a statutory overlay. He expresses wonder that I could not have recognized the consequence of such an error, viz that the two species of power were inextricably linked and thus that my critique based on their elision was unfounded. I did not in fact commit any such error. More important is the fact that Hamburger entirely misses the point that I was making. It can be put very simply.

The reality was that at least $95 \%$ of regulatory activity was based purely on statute. It had nothing to do with the prerogative. The regulatory statutes were not based on prerogative power, nor were they dependent on it. They were based four-square on ordinary statute enacted in the normal manner by the sovereign Parliament, and that was how they were interpreted by the courts. It is therefore both unwarranted and misleading for Hamburger to frame his critique of administrative law repeatedly in terms such as: the "extralegal character of the absolute prerogative [which] has been revived by contemporary administrative power"; ${ }^{40}$ or that administrative legislation or rulemaking constitutes a return to prerogative lawmaking, and that statute cannot cloak it with constitutional legitimacy; ${ }^{41}$ or the elision of

\footnotetext{
${ }^{39}$ P. CRaig, Prerogative, Precedent and Power, in C. Forsyth AND I. Hare (EDS), The Golden Metwand AND THE CROOKED CORD, ESSAYS IN HONOUR OF SIR WILLIAM WADE (1998), pp. 65-89

${ }^{40}$ HAMBURGER, supra note 5 , at 3 .

${ }^{41}$ HAMBURGER, supra note 1, at 48-9, 56-7, 63, 82, 128.
} 
"prerogative or administrative adjudication." 42 The fact that some prerogative power had a statutory overlay is both undeniable and irrelevant to the point just made.

The historic reality is that Parliament repeatedly enacted statutes being fully cognizant of the regime therein for administrative delivery, and fully cognizant of the normative choice that this entailed. It did not regard the regime thus established as extralegal, and nor did the courts. It suits Hamburger's overall thesis to portray events in terms of the prerogative, or the extralegal character of the absolute prerogative, or one of the similar variations that adorn his writing. This is neither an accurate picture of the historical provenance of the very great majority of administrative power, nor is it an accurate picture of its normative underpinning. It is, as I stated in the earlier article, an unwarranted elision of the two sources of power, and there is nothing in Hamburger's reply that comes anywhere close to recognizing or addressing this issue.

The need to distinguish the two sources of power, and their relative hierarchy, is revealed sharply by the case law on the way in which the prerogative can be qualified by statute. It underpins the principle that where the democratically elected Parliament had regulated an area then the executive had to follow the conditions laid down in the relevant statutes, and could not seek a more advantageous result by reliance on the prerogative. ${ }^{43}$ It was precisely because the statute had the imprimatur of Parliament that it trumped the prerogative, and it was precisely because of this normative distinction that no one in the seventeenth century or later would elide the two.

\section{THE MEANING OF LEGISLATIVE AND JUDICIAL}

\footnotetext{
${ }^{42}$ Id. at 136.

${ }^{43}$ Attorney General v. De Keyser's Royal Hotel [1920] A.C. 508.
} 
Hamburger's thesis is dependent on definition of legislative acts and judicial acts, since it is the former that is at stake in discussion of extralegal administrative rulemaking, and the latter that is at stake through what he perceives to be extralegal administrative adjudication. In my earlier article I criticized in detail the meaning that he ascribed to the terms legislative and judicial. Hamburger is dismissive of such critique, and does not address the issues that I raised. He contends that my critique was grounded on the division between legislative and judicial power, and responds that this was not important for his overall project since he regards all extralegal rulemaking and adjudication as unlawful. ${ }^{44}$

It is common for an academic faced by wide-ranging criticism to dismiss the argument summarily, contending that his academic protagonist is firing blanks, in the sense of addressing an issue that is unimportant. This strategy thereby obviates the need to respond to an argument to which one has no answer, and carries the added plus of being couched in academically dismissive tones. Let us leave such academic games and return to reality.

The detailed critique that I made was not directed at the divide between legislative and judicial acts. It was directed at the meaning that Hamburger ascribed to each of these terms. This was crucial for Hamburger's project. He regards administrative rulemaking as extralegal, and had therefore to take some view as to what counts as a legislative rule that was then off bounds for the administration. He regards administrative adjudication as extralegal and thus by parity of reason he had to provide some definition of the term judicial so as to define the type of decision-making that was off bounds for the administration. My critique was nothing to do with the boundary between legislative and judicial. It had everything to do with the soundness of Hamburger's interpretation of the term legislative, and the term judicial. It was thus an immanent critique of the meaning that he chose to assign to each of

\footnotetext{
${ }^{44}$ HAMBURGER, supra note 5, at 27.
} 
these terms. ${ }^{45}$ The reader who is so inclined can consider this detailed assessment in the earlier article. It is nonetheless important for present purposes to be cognizant of this material, since it is reveals more generally the infirmity that besets Hamburger's thesis. The difficulties that inform Hamburger's definition of the term judicial can be taken by way of example.

For Hamburger, administrative adjudication is only constitutionally proscribed where it involves the exercise of judicial power, which is said to belong exclusively to the courts. It is the power to make binding adjudications, in the sense that they are not merely determinative, "but more basically in the sense that they bound subjects, whether by obliging them to appear, to testify, to produce their documents, to pay damages, or otherwise relinquish their liberty or rights." ${ }^{46}$ This definition is seminal, since it signifies the boundary between what is lawful and unlawful according to Hamburger's mode of thinking. It is however deeply problematic for four reasons.

The first is that it is crucially ambiguous. On one reading his formulation of judicial appears to mean that exercise of any power that bound individuals in any way would be judicial and hence off bounds to the administration: the obligation to appear, or to testify, or to produce their documents, or to pay damages, or otherwise relinquish liberty or rights, would, read disjunctively, suffice to condemn administrative power as illegitimate. This does not withstand examination in terms of the legislation, or the case law interpreting it. $^{47}$ Parliament repeatedly gave the administration power of these kinds, and the courts did not regard this as unconstitutional or illegitimate. The alternative reading is that the forbidden "judicial" line would only be crossed if the administration exercised most, or all, of the

\footnotetext{
${ }^{45}$ CRAIG, supra note 2 , at 17-19, 34-8.

${ }^{46}$ HAMBURGER, supra note 1 , at 191.

${ }^{47}$ CRAIG, supra note 2, at Part III D.
} 
preceding powers. This is, however, equally problematic. Is it most, or is it all? Are they all equally important? Powers to fine and imprison had to be exercised by courts of record. ${ }^{48}$ However the very meaning of court of record and the concept of the record are complex. ${ }^{49}$ The legal reality was that a body with such power was deemed to be a court of record, ${ }^{50}$ but it should also be noted that this served to limit judicial oversight by limiting contestation of the finding embodied in the roll that constituted the record. ${ }^{51}$

Secondly, Hamburger's definition of judicial power is also problematic in relation to his treatment of benefits and privileges. He makes it clear that the concept of judicial power and binding adjudication "did not include decisions about government benefits or privileges, unless they had 'vested' and become rights." ${ }^{, 52}$ This however elides two quite distinct issues: what degree of judicial protection should be accorded by administrative law to interests that do not qualify as rights stricto sensu, and how should we characterize the process by which this determination is made. The answer to the former, whatsoever it might be, tells one nothing in and of itself as to the latter. It might be decided to diminish legal protection for interests that do not qualify as vested rights, but the decision thus made can still properly be regarded as an exercise of judicial power and adjudication that gives effect to this normative choice.

Thirdly, Hamburger draws a wholly implausible distinction between judicial power/binding adjudication, and what he terms executive adjudication as a mechanism for determining and giving notice of legal duties. In the latter instance Hamburger contends that

\footnotetext{
${ }^{48}$ DR. GROENVELT v. DR. BURWELL (1700) 1 Ld. Raym. 454 at 467.

${ }^{49}$ See S.E. Thorne, EsSAYs in English Legal History (1985), 61-74; AMNON Rubinstein, JuRisdiction AND ILLEGALITY (1965), 54-80.

${ }^{50}$ DR. Groenvelt v. Dr. BuRwell (1700) 1 Ld. Raym. 454; KeMP v. NeVILle (1861) 10 C.B. (N.S.) 523 at 547.

${ }^{51}$ KEMP, supra note 50, at 547-552.

${ }^{52}$ HAMBURGER, supra note 1, at 191.
} 
the "law rather than any executive determination that was binding". ${ }^{53}$ Thus in relation to administrative assessment of taxes, the binding obligation is said to flow from the law, with the consequence that the executive could lawfully make such determinations without infringing any principle concerning the exercise of judicial power by the administration. This does not withstand examination. In a reductionist sense it is always the "law" that is binding. Excise statutes were in fact notoriously complex, and considerable judgment was required in the application of the statutory rules. ${ }^{54}$ If notwithstanding this the resultant decision is regarded as "non-judicial” on Hamburger's definitional taxonomy then it begs the question as to which of the many other statutory responsibilities cast on administrators should also be classified in this manner, to which Hamburger provides no answer.

Fourthly, Hamburger's analysis of the term judicial reveals the same blend of ignorance and disdain for the primary sources, case law and statute, that characterizes his work more generally. Thus the case law furnishes no support whatsoever for Hamburger's distinction as to when administrative adjudication was regarded as legitimate and when it was not. To the contrary, the administrative decisions were determinative for those affected, unless successfully challenged, and in all such instances those affected were bound de facto and de jure by them, which was precisely why they challenged them. This was recognized and accepted by the courts, which was why they subjected such determinations to judicial review. They did not, however, regard the administrative adjudication that led to such determinations as constitutionally invalid or illegitimate. The administration was discharging the responsibility vested in it by Parliament, and making the decisions required in furtherance of the statutory grant of authority. The decisions were subject to legal accountability via judicial review, and if they successfully negotiated that hurdle that was an end to the matter.

\footnotetext{
${ }^{53}$ Id. at 203.

${ }^{54}$ John Brewer, The Sinews OF POWER, WAR, MONEY AND THE ENGLISH STATE 1688-1783 (1988).
} 
The same gap between his theory and reality is evident in relation to legislation. There is a signal failure to test whether his definition of the term judicial coheres with the types of power accorded to the administration by the legislature. This is clearly crucial for any informed analysis: if the answer is yes then it lends weight to his thesis, if the answer is no then the thesis must either be discarded or recast in normative terms, rather than being descriptive of reality. The answer is that statutes regularly gave administrators 'judicial' powers of a kind that Hamburger believes should not have been so assigned. ${ }^{55}$ The reader of Hamburger's work would not, however, know this, since he does not test his hypothesis through detailed scrutiny of the powers given to the administration in different subject matter areas.

\section{METHOdOLOGY}

The fourth major error that pervades Hamburger's work is methodological. Hamburger contends that my earlier article exhibited a methodological error, in that my argument was constructed on some form of stark Austinian positivism, whereby I placed all weight on positivist sources to the exclusion of constitutional principle or constitutional ideals. Thus for Hamburger, "Craig's most basic Austinian error is his use of positive measures of law to understand constitutional ideals", such that "he repeatedly focuses on what Parliament or the courts permitted or barred, as if ideas about the English constitution can be measured by looking simply at what Parliament and the courts did". Hamburger acknowledges that I am "undoubtedly correct that Parliament authorized English administrative bodies and that neither Parliament nor the courts rejected most English instances of administrative power as unlawful" ${ }^{56}$ He nonetheless qualifies this by stating that Parliament and the courts were not

\footnotetext{
${ }^{55}$ CRAIG, supra note 2, at Part III D.

${ }^{56}$ HAMBURGER, supra note 5, at 16.
} 
the end of the matter, and that it was very odd, especially in a country such as England, not also to consider ideals. The reality is, as will be seen from the ensuing discussion, that it is Hamburger whose methodology is seriously defective, with profound consequences for the thesis that he seeks to advance. This is so for four reasons.

First, I am not an Austinian positivist, nor indeed a Hartian positivist, nor is there anything whatsoever in the earlier article to sustain this. Having said that I make no apology whatsoever for giving great weight to positivist sources in terms of what Parliament routinely did over 300 hundred years, and that is equally so in relation to the courts. Let us recall the object of the inquiry. It is to test the veracity of Hamburger's far-reaching thesis to the effect that administrative law should be regarded as unlawful and illegitimate, and what English law has to tell us about this thesis. The fact that Parliament enacted literally thousands of regulatory statutes granting powers and duties to the administration is central to testing that hypothesis, since it is assuredly crucial to any empirical claim as to how administration was perceived by the legislature during this period. This is more especially so because many of these statutes gave the administration powers of a kind that Hamburger believes that they should not have been accorded. The same is true in relation to the courts. Hamburger is disdainful of statistics about the incidence of judicial review, while ignoring their obvious relevance to the present inquiry. The courts' jurisprudence provides no foundation for the claim that administrative authorities, or the decisions that they made, were perceived to be extralegal in the sense that is central to Hamburger's thesis. To the contrary, their approach was, as explained above and in greater detail in the earlier article, to regard such grants of power, whether in terms of rulemaking or adjudication, as lawful and legitimate, subject to oversight through judicial review.

Secondly, Hamburger faces a further methodological problem with respect to courts. He wants to do legal history, but does not invest the time or effort to read beyond a small 
group of legal cases in order to understand what was really going on. If you wish to make claims concerning how administration was perceived in England, and if you wish to sustain a far-reaching thesis about the extralegal nature of such power, then what the courts were doing is crucial. They were not the only game in town, and they are not the only materials that we should be considering when appraising his thesis, but their decisions are nonetheless a condition precedent for any reasoned conclusion. This means a willingness to look in detail into the principal areas of administration and how they were treated by the courts when engaged in judicial review, direct or collateral. Hamburger has not done this, but wants us to treat his conclusions as canonical nonetheless. It is indeed extraordinary that an academic should purport to base such far-reaching conclusions on such scant evidence. It is bad scholarship, both legal and historical.

Thirdly, Hamburger's claim that I ignored constitutional ideals is quite wrong. $\mathrm{He}$ complains loudly that I ignored constitutional ideals when depicting the pattern of administration and how it was viewed, concentrating solely on positivist sources in terms of what the legislature and the courts did. There is considerable confusion here, and it is reflective once again of Hamburger's lack of knowledge of, and interest in, what the courts were doing in this area of the law. The reality was that the courts developed constitutional ideals that shaped this entire area of the law, and provided the principled architecture against which the administration operated. The courts built the principles of judicial review grounded on the rule of law from the late sixteenth century onwards. This was central to the account that I gave in the earlier article. The fabric of judicial review was created from constitutional principles designed to render the exercise of public power accountable. Legal accountability was not the only mechanism for holding the administration to account; it coexisted with precepts of political accountability and with checks that were internal to the administration. It was moreover the courts that fashioned the constitutional principles that shaped the limits of 
prerogative power, denying the monarch a general regulatory power in the Case of Proclamations, ${ }^{57}$ and denying it judicial capacity in Prohibitions del Roy. ${ }^{58}$

The fourth methodological point concerns the nature of constitutional inquiry, and the weight that we ascribe to evidence, when undertaking it. This issue is thrown into sharp relief when we ask what precisely Hamburger thinks were the constitutional ideals that have on his view been unjustifiably missed in my analysis. He provides little by way of detailed response. We are merely told in vague terms that English constitutional ideals went in divergent directions, such that one vision accepted as constitutional whatever Parliament did, thus reducing the constitution to Parliamentary supremacy, albeit with some limiting ideals; while another vision espoused by some lawyers and taken further by radical Whigs, insisted that there were constitutional limits on what Parliament could lawfully do, with the consequence that any exercise of binding power outside the courts and legislature was unlawful. ${ }^{59}$ The salient issue is what this tells us as to the sustainability of Hamburger's thesis, and how we as scholars should assess that thesis in the light of the evidence overall.

We have then the following dossier of evidence. We have statutes repeatedly enacted, amended and improved in particular areas, often over three hundred years. This was true for the legislation relating to areas such as sewers, bankruptcy, trade regulation, police power, inclosures, turnpikes and the poor law. The statutes gave very considerable powers to the administration; the amendments were almost always designed to increase such power or to close lacunae that had become apparent; and they were enacted by Parliaments of every political hue and colour. Legislation truly was an iterative process, with learning by doing. The legislation thus enacted commonly gave the administration power of a kind that

\footnotetext{
${ }^{57}$ (1611) 12 Co. Rep. 74.

58 (1607) 12 Co. Rep. 63.

${ }^{59}$ HAMBURGER, supra note 5, at 17.
} 
Hamburger would deprecate, and there was a very great deal of it, there being thousands of such regulatory statutes. The legislation thus enacted was not regarded as embodying the grant of extralegal power to the body charged with its administration.

We then add to this dossier of evidence the fact that the courts over this same period accepted such legislation, and did not regard the power thereby accorded to the administration to be infirm or extralegal in the manner articulated by Hamburger. There were once again thousands of such cases. There is moreover a further strand to this evidential inquiry. It is instructive and not fortuitous that when Hamburger seeks evidence of constitutional ideals he looks for evidence that regards the administration in a bad light. It is something dangerous, unnatural, the bearer of extralegal power that should be constitutionally deprecated thereby sustaining his thesis. This, taken together with the fact that he has not studied the case law in any depth, causes him to miss an important dimension of the judicial role. It is clear from the courts' jurisprudence that they generally regarded the regulatory statutes as embodying valuable social purposes that had been duly enacted by Parliament, and should therefore be effectively applied. Judicial review actions were the vehicle through which this commonly occurred. The claimant would seek review, the court would find that the claim was not made out, and it would take the opportunity presented by the case to interpret the enabling legislation so as best to attain its regulatory objective. ${ }^{60}$ This did not mean that the courts always got it right, and the result of regulatory litigation could be contentious then as it is now. It did mean that judicial power was regularly used in the preceding manner, with the courts using judicial review both as the mechanism for ensuring legal accountability, and also as the vehicle through which statutes could be interpreted so as to achieve the social purposes embodied therein.

\footnotetext{
${ }^{60}$ P. Craig, UK, EU and Global Administrative Law: Foundations and Challenges (2015), pp. 62-5, 69-95.
} 
Notwithstanding all of the above Hamburger would nonetheless have us believe that his thesis about the extralegal nature of power accorded to the administration should be regarded as accurately capturing English legal and historical thought because some believed that binding power should only reside in the legislature and the courts, or that some political statements could be found deprecating the power accorded in a particular statute.

This is an extraordinary claim, and is unsustainable by any metric of legal or historical inquiry, more especially given the breadth of the principle that he seeks to sustain by recourse to this evidence, viz that an entire body of law should be regarded as unlawful and illegitimate. If historical and legal inquiry can be conducted in this manner then it can be used to justify any conclusion that the writer so wishes, irrespective of its fit with the relevant materials. The practice of the legislature and the courts over three hundred years as evidenced in a very great deal of legislation and case law are to be brushed aside by recourse to brief mention of constitutional ideals, as if this was some magical trump that could alter the conclusion to be drawn from the primary materials.

Hamburger's juxtaposition of 'positive law' in terms of statute/case law, as opposed to 'constitutional ideals', is moreover clearly wrong in and of itself. It is predicated on the assumption that the view taken of administration in the legislation and case law is somehow value-free, as opposed to discourse cast in terms of constitutional ideals that really goes to the normative heart of the matter. This does not withstand examination. The legislation and the case law were both premised on a normative view about the place of the administration in the legal and political order. That view is starkly opposed to Hamburger's characterization of administrative decisions as extralegal, irregular or extraordinary, and it is equally inconsistent with Hamburger's attempts to generalize from the Star Chamber and the Statute of Proclamations to the conclusion that administrative adjudication and rulemaking should in general be seen as unlawful. The reality is that Hamburger has a thesis that he wants to be 
correct, even though it is unsustainable in the light of the overwhelming preponderance of the evidence, with the consequence that he simply chooses to ignore the data that does not fit with his desired conclusion.

\section{CONCLUSION}

It is fitting by way of conclusion to return to the simple foundations of academic scholarship. It is axiomatic in this regard that the broader the proposition that is advanced the better must be the argument that supports it. The claim that an entire body of law should be perceived as unlawful is about as broad as it gets within a liberal democratic polity, since there is not much further to go without calling in question the very status of the polity itself. The foundation for such a claim will perforce rest on an admixture of theory and empirical evidence. It is incumbent on the proponent to proffer this evidence and subject it to searching scrutiny before pronouncing the conclusion justified. Hamburger's thesis comes nowhere close to satisfying these simple criteria for the sustainability of an academic hypothesis.

The argument is grounded in his construct of extralegal power, which is the theoretical foundation for the thesis that administrative law is unlawful. Hamburger's theory concerning extralegal power is, however, untenable in terms of principle, is wholly inconsistent with positive law in terms of how the courts conceived of the legitimacy and status of administrative norms, and is incompatible moreover with how English law regards the imposition of duties and powers on private parties.

Hamburger's argument is equally unsustainable when judged in terms of empirical evidence. He insists on the correctness of his chosen interpretation of events such as the demise of Star Chamber, and the constitutional lessons to be learned from the repeal of the Statute of Proclamations. He repeatedly criticizes any who question his conclusion that these reveal the extralegal infirmity of all administrative adjudication and rulemaking. He depicts 
himself as the guardian of true historic rectitude. The reality is quite the contrary. The firmness of his belief is based on a particular interpretation of highly selective historical sources, which leads inevitably to indefensible conclusions. He ignores the very large number of regulatory statutes enacted over two centuries through which Parliament repeatedly evinced its willingness to accord the administration the very powers that Hamburger believes were illegitimate. He ignores the thousands of cases in which the courts accepted the legality of administrative determinations, according them binding force subject to judicial review, with no hint whatsoever that the administration should be conceived of as extralegal in the manner for which Hamburger contends. His interpretation of the evidence that he does consider is itself highly questionable, since it is based on normative assumptions that are untenable. Thus he is unwilling to accept any normative distinction between Star Chamber and the paradigm instance of administrative adjudication by an administrative authority charged to perform the specific task by statute. He is likewise unwilling to acknowledge the clear normative distinction between the Statute of Proclamations and the paradigm instance of rulemaking by the administration.

US courts and commentators will rightly form their own view of the salience of Philip Hamburger's arguments in the context of modern US administrative law, framed as it by the US constitution. They may be influenced in this respect by the English experience, given that it is central to Hamburger's analysis. The purpose of this article and that which preceded it is to set the record straight as to what the historical record actually reveals. The reality is that English law provides no support for the broad thesis that Hamburger advances. It is indeed difficult to think of any instance where a thesis of such breadth has been advanced with so little evidence to support it, more especially where there is so much evidence to the contrary. 